\title{
ENVIRONMENTAL AUDIT, A POSSIBLE SOURCE OF INFORMATION FOR FINANCIAL AUDITORS
}

\author{
Nicolae Todea ${ }^{l}$ \\ Ionela Cornelia Stanciu ${ }^{2}$ \\ Ana Maria Joldoş (Udrea) ${ }^{3}$
}

\begin{abstract}
The purpose of this article is to present certain aspects regarding environmental audit and how it is perceived by the accounting profession, especially by financial auditors. The main objectives taken into account when writing the article was to define the concept of environmental audit, to present how financial auditors get involved within environmental audit, both internationally and in Romania. The scientific approach is based on information from national literature, European and international practice regarding environmental audit and the implication of accounting professionals in this activity. The results of the research conducted in this paper have shown that the accounting profession at international level, such as the case of New Zeeland, as well as at national level, is only slightly involved in environmental audit due to the fact that this type of audit is an activity that is not mandatory, being used for the entity's own use as opposed to financial audit, which is mandatory and is stipulated by accounting regulations in force and is standardized.
\end{abstract}

Key words: environmental audit, financial audit, environmental aspects, accounting profession

JEL codes: M41, O13, Q59

\section{Introduction}

Environmental auditing is a voluntary activity for most organizations. Over the last decade, the number of organizations relying on environmental audits has increased exponentially. For instance, in the last 10 years more than 88,000 organizations worldwide have certified their environmental management systems (EMS) to ISO 14001 (Peglau, 2005), the international EMS standard which requires external audits as a condition of certification. Outside of the ISO 14001 framework, many more companies have utilized other types of external environmental audits, implemented internal audits, or adopted both types of auditing schemes. Recently, Parker (2005) reviewed the research on social and environmental accountability that was published between 1988 and 2003 in six leading interdisciplinary accounting journals. He found that of the 233 published articles assessing social and environmental accountability, 140 (66\%) specifically addressed environmental issues. After further evaluating these papers, Parker (2005) concluded that, while scholarship recognizes environmental accountability as an important research area, the topic of environmental auditing is under-researched by authors publishing in leading interdisciplinary accounting journals (Darnall, 2009).

The objectives taken into account in this research were: presentation of the environmental audit concept, presentation of the environmental audit's stages compared with the stages of financial audit, presentation of a case study regarding the involvement of Romanian financial auditors in conducting an environmental audit assignment, as well as identifying the involvement

\footnotetext{
1 “1 Decembrie 1918” University of Alba Iulia, Faculty of Science, Romania, e-mail: ntodea@uab.ro

${ }^{2}$ Valahia University of Târgovişte, Doctoral School, Romania, e-mail: s_ionela09@yahoo.com

${ }^{3}$ Valahia University of Târgovişte, Doctoral School, Romania, e-mail: anajoldos232004@yahoo.com
} 
and participation limits of financial auditors in environmental audit. The presented case study had as starting points two studies, one of them was conducted at international level by Christina Chiang and Margaret Lightbody (2004) and presented the involvement of the accounting profession in New Zeeland within environmental audit, and the second study conducted by Ienciu (2009) regarded the involvement of Romanian financial auditors in environmental audit. These two studies were rounded by a research of how entities are getting involved in environmental protection activities and how financial auditors are participating in environmental audit together with experts in this field (engineers, environmental specialists). The results of these three studies will be presented in the last part of the paper.

\section{Research Methodology}

The methodology is a complex word (concept), etymologically composed of method's and logos which mean "method" and "science", in Greek, and free translation "science method", the science of conception, choice and use of method in the investigation process of economic phenomena. The research methodology is the theory and practice methods, an activity that is studying the essence, nature, status, definition, classification, etc. the construction of explanatory models.

The need for scientific research in accounting is particularly important today, more than that pluridisciplinarity in accounting research is necessary and sometimes profitable. Scientific research is necessary to seek and find solutions or answers to immediate problems and to achieve reasonable theorizing issues of environmental auditing and accounting professionals involved in its performance, which may be an important source of information for auditors when prepare the audit report and audit opinion on the audited financial statements.

The research methodology used in this paper consisted of studying the literature in the field, as well as factual documentation at a number of entities in Alba County to see how they are involving accounting professionals in environmental auditing, and to see if these professionals take into account the environmental problems that exist at the level of the entity while conducting the financial/statutory audit. To achieve the objectives, this article used as main research methods the following: qualitative analysis, which includes the comparison method, a method targeting the presentation of the environmental audit's stages and the stages of financial audit; synthesis - this research method is used when drawing conclusions that aim to explain and valuate the involvement of financial auditors in environmental audit and the main difficulties encountered by them when conducting this type of audit; the case study method is used to present the involvement of accounting professionals in environmental audit; and the questionnaire method was used to develop the questionnaire that was send to the entities in Alba County.

In order to achieve this approach we turned to research methods like documentation, analysis, synthesis, comparison, which are part of the positivist research philosophy.

\section{Literature review}

According to Mathews (1997) and Matiş and Ienciu (2010), the current stage of knowledge in the field of environmental accounting has known four stages in its development (1970-1980, 1981-1994, 1995-2001, 2002-onwards), but our research will approach only the researches and studies conducted in the last two stages because this is the period when the concept of environmental audit started to be developed. Between 1995 and 2001, environmental accounting, both in theory and in practice, started to be widely approached especially in developed countries, new subdomains of environmental accounting begun to develop, such as environmental management accounting and environmental audit, this period being named "the cornerstone" of environmental accounting, with managers and accountants also showing interest.

Environmental audit is a subdomain that begins to garner interest due to the implementation of standards regarding environmental standards, which contain a part related to audit or verification. 
In terms of international specialized magazines and journals that approach environmental audit, these are: Managerial Auditing Journal, Environmental Management Journal, Accounting, Organizations and Society Journal, Accounting Forum, Accounting, Auditing and Accountability Journal, Total Quality Management Journal, Greener Management International Journal, Journal of Accounting and Public Policy, The European Accounting Review, Environmental Quality Management, The Journal of Corporate Accounting and Finance, available in international data bases: www.sciencedirect.com, www.search.ebscohost.com, www.jstor.org, www.emeraldinsight.com, www.springerlink.com. In terms of the Romanian publications that address the issue of environmental audit, there aren't many journals of this type, but the presented studies show a growing interest towards this area: Annales Universitatis Apulensis Series Oeconomica, University of Oradea Annals, Economic Science Series, Management Accounting and Informatics Journal, Financial Audit Journal, Euroeconomica, Tibiscus Magazine, Annals of „Valahia” University Târgovişte, Economic Science Section.

A new subfield of environmental accounting begins to develop around 70 years environmental auditing, due to the implementation of standards organizations in environmental management. The main outstanding contributions to the development of research in this subfield are: Gray and Symon (1991), Power (1991), Maundres and Burritt (1991), Tozer and Mathews (1994), Thompson and Wilson (1994), Matbly et al. (1995), Unhee (1997), Elliott and Patton (1998), Collison and Slomp (2000), Solomon (2000). Karapetrovic and Wilborn (2001), Cahill (2002), Emery amd Watson (2003), Watson and MacKay (2003), Chiang and Lightbody (2004), Dixon et al. (2004), De Moor and De Beelde (2005), Vinten (2006), Darnall et al. (2009). Regarding the first Romanian research studies which deal with the audit work environment in Romania is that of Borza (2007), followed by Horomnea and Nuţă (2007), Bețianu (2008), Dascalu et al. (2009), Caraiani et al. (2010).

The conclusion that may be drawn is that researches in the area of environmental audit have grown considerably due to the importance that environmental issues are starting to have both for entities and for society.

\section{Conceptual delimitations regarding environmental audit}

Following the Conference in Stockholm in 1972, the awareness of environmental threats has included a large scope of the population and enterprisers. As a result, the concept of environmental audit emerged, which initially meant compliance with the environmental legislation. The specialized literature confirms that the first environmental audit was conducted in the 1970s in the United States of America and subsequently this concept has grown and was performed by a growing number of entities, especially in developed countries.

The audit, regardless of its nature, requires commitment to the audit philosophy, its social norms and a joint investment in this technical practice. Society is increasingly more committed to self-observance through various types of auditing practices. The rational behind this commitment is the notion that people must be responsible for their actions, and this responsibility must be verified. Being related to the environment, the environmental audit has evolved from a tool used by companies to ensure compliance with environmental norms to a management based style of selfassessment, emphasizing systems and self-informing (Power, 1997).

The International Chamber of Commerce (ICC, 1991) defines environmental audit as a management tool comprising a systematic, documented, periodic and objective evaluation of how well environmental organization, management and equipment are performing with the aim of helping to safeguard the environment by: facilitating management control of environmental practices and assessing compliance with company policies, which would include meeting regulatory requirements. According to the Confederation of British Industry, environmental audit represents the systematic examination of the interactions between economic and environmental operations. These include emissions into the atmosphere, water, soil, effects on neighboring areas, landscapes 
and public perception of the community regarding the company's activities. Environmental audit doesn't analyses all legal provisions, but provides a strategic approach for the activities of the entity (Bețianu Leontina et.al, 2008).

The Council of the European Union (1993) defines environmental audit as a management tool consisting of a systemic, documented, objective and regular evaluation of the entity's performance, of the management system and of the processes designed to protect the environment in order to control the practices that have an environmental impact and to assess their conformity with the entity's policies.

According to the International Standard ISO 14050 Environmental Management, environmental audit represents the systemic and documented process of verifying audit evidences obtained and assessed objectively in order to determine if activities, events, conditions, established environmental management systems or information about them are in accordance with audit criteria, and communicating the results of this process to the client.

Order no. 50/14.01.2004 on the Establishment of the organization and coordination procedure of the Eco-Management and Audit Scheme (EMAS) defines environmental audit as a managerial tool of systemic, documented, regular and objective assessment of the organization's performance, the management system and the processes developed for environmental protection, with the purpose to facilitate managerial control of practices with potential environmental impact and to assess compliance with environmental policies, including achieving the environmental objectives and targets of the organization.

In our opinion, environmental audit is a systematic analysis of the entity's environmental impact. Environmental audit focuses on those aspects of the operations that have a significant impact over the environment. As can be seen from above, environmental audit represents a mean for improvement, being recommended to conduct it regularly in order to avoid the risk of failure to comply with environmental regulations in force.

\section{Stages of environmental audit}

The main objective taken into account in this sub-chapter is to present the environmental audit stages compared with the stages of financial audit. This section discusses the different parts of an environmental audit. These phases are compared with those typically found in a financial statement audit. A typical financial statement audit can be divided into four phases. This structure is based on professional standards and an analysis of the dominant practice, and is also reflected in academic research. Gorstein and Craig (1984), for example, divided the audit in three phases: the initial planning, program development, and program execution. Cohen and Hanno (2000) investigated the impact of corporate governance and management philosophy on judgments in the preplanning and planning phase. The former phase corresponds with the client acceptance phase. This reflects the distinction, which is generally recognized currently, of the "client acceptance", phase, the "planning" phase, the "testing and evidence" phase, and the "evaluation and reporting" phase. This division can be linked to the U.S. auditing standards and the International Standards on Auditing (De Moor Philippe, 2005).

Table no. 1 presents a comparative analysis between the stages of the environmental audit and financial audit steps: 
Table no. 1

\section{Comparative analysis between financial audit steps and stages} environmental audit

\begin{tabular}{|c|c|c|c|}
\hline \multicolumn{2}{|r|}{ Standard financial audit } & \multicolumn{2}{|c|}{ Environmental audit } \\
\hline $\begin{array}{c}\text { Client } \\
\text { acceptance }\end{array}$ & $\begin{array}{l}\text { Evaluate the background of the client and } \\
\text { reasons for the audit } \\
\text { Communicate with previous auditor } \\
\text { Determine need for the other professionals } \\
\text { Prepare client proposal } \\
\text { Obtain engagement letter } \\
\text { Select staff to perform the audit }\end{array}$ & $\begin{array}{l}\text { Select and } \\
\text { schedule facility to } \\
\text { audit } \\
\text { Select audit team } \\
\text { members }\end{array}$ & $\begin{array}{l}\text { Pre-audit } \\
\text { activities }\end{array}$ \\
\hline $\begin{array}{l}\text { Planning } \\
\text { the audit }\end{array}$ & $\begin{array}{l}\text { Obtain company and industry background } \\
\text { information } \\
\text { Investigate legal information } \\
\text { Perform initial analytical procedures } \\
\text { Perform procedures to obtain an understanding } \\
\text { of internal control } \\
\text { Based on the evidence, assess risk and set } \\
\text { materiality } \\
\text { Understand internal control and assess the risk } \\
\text { Develop an overall audit plan and program }\end{array}$ & $\begin{array}{l}\text { Contact facility } \\
\text { and plan audit } \\
\text { Identify and } \\
\text { understand } \\
\text { management } \\
\text { control system } \\
\text { Assess } \\
\text { management } \\
\text { control system }\end{array}$ & \\
\hline $\begin{array}{c}\text { Testing } \\
\text { and } \\
\text { evidence }\end{array}$ & $\begin{array}{l}\text { Test of controls } \\
\text { Conduct substantive test of transactions } \\
\text { Analytical procedures } \\
\text { Test details of balances } \\
\text { Obtain management representation letter } \\
\text { Accumulate final evidence and search for } \\
\text { unrecorded liabilities }\end{array}$ & $\begin{array}{l}\text { Gather } \\
\text { evidence }\end{array}$ & \\
\hline $\begin{array}{l}\text { Evaluation } \\
\text { and } \\
\text { reporting }\end{array}$ & $\begin{array}{l}\text { Review for contingent liabilities } \\
\text { Perform overall review } \\
\text { Perform procedures to identify subsequent } \\
\text { events } \\
\text { Review financial statements and other report } \\
\text { material } \\
\text { Perform wrap-up procedures } \\
\text { Prepare maters of attention for partners } \\
\text { Report to the board of directors } \\
\text { Prepare audit report }\end{array}$ & $\begin{array}{l}\text { Evaluate audit } \\
\text { findings } \\
\text { Report findings to } \\
\text { facility } \\
\text { Issue draft report } \\
\text { Issue final report } \\
\text { Action plan } \\
\text { preparation and } \\
\text { implementation } \\
\text { Follow-up action } \\
\text { plan }\end{array}$ & $\begin{array}{l}\text { Post- } \\
\text { audit } \\
\text { activities }\end{array}$ \\
\hline
\end{tabular}

Source: P. De Moor, De Beelde Ignance, Environmental Auditing and the Role of the

Accountancy Profession: A Literature Review, Environmental Management Journal, 2005, vol. 36, nr. 2, p. 210

Financial auditing and environmental auditing have similar structures. The assessment of control systems is essential in both systems. This supports the argument that auditors trained traditionally to assess financial statements may play a key role in environmental audit. In this audit, the audit plan should identify the objectives and the auditing scope, what procedures will be applied, who will conduct the audit and when the procedures will be performed (HKG, 2004).

The conclusion that may be drawn here is that there are differences between environmental auditing and the auditing of financial statements. One difference regards the need that environmental auditors have for the support of the managers before beginning the audit, and that goals and objectives should be defined and an action plan should be designed and implemented. 


\section{The involvement of accounting professionals in environmental auditing}

While examining the role of the auditor is important to understand that environmental audits have changed over time. Initially, the environmental auditor focused on technical problems and on issues of compliance with the legislation, and was a role generally undertaken by professionals from outside accounting and from outside the entity. As environmental audit evolved, it was acknowledged that the role of the environmental auditor extends beyond legal compliance going all the way to the management mechanisms in an entity, and there's a growing pressure for them to be revised internally on a regular basis (Power, 1997).

Lately, the international profession of accountant was quite vocal in requesting auditors and accountants to undertake a central role in designing and performing environmental audits in general and audits of environmental management systems in particular. Due to the fact that until now, there is no mandatory general framework for environmental auditing, accountants and auditors are reluctant to get involved in performing environmental audits, preferring to operate in fields where there is a generally accepted framework, such as financial audit, internal audit, financial consultancy, evaluation, legal and extra judicial expertise.

The International Chamber of Commerce has drawn attention to the parallels between financial audit and environmental audit: "a standard methodology, an emphasis on verifying compliance against standards, and the use of some auditing techniques" (ICC, 1991). But, ICC has also shown the differences. Financial audit is statutory, annual, certificatory, external, based on Generally Accepted Accounting Principles and focused upon financial accounting, while environmental audits are voluntary, of variable frequency, managerially oriented, internal, relative to varied standards of performance and focused on environmental issues.

In a study conducted by Lodhia (2003), the accountants hired by chartered accountants firms in Fiji stated that their companies were not involved in environmental accounting because of a lack of demand. The role and contribution of external financial auditors to environmental audit have also been researched in New Zeeland (Christina Chiang, Margaret Lightbody, 2004). Although Chiang and Lightbody (2004) acknowledged the development potential of the auditing profession in this direction, they concluded that financial auditors in New Zeeland overlook these possibilities. Auditors in New Zeeland were engaging in environmental auditing only because of outside pressure from others, for example, pressure from clients, instead on proactively exploring this new market segment. Nevertheless, they observed that the number of auditors involved in environmental auditing is growing.

We can see that the auditing profession has a minor implication in conducting environmental auditing; its execution requires a series of abilities, among which the most important is teamwork, which involves auditors, accountants, engineers and environmental experts in order to resolve the environmental problems that an entity may face.

But what is the role of financial auditors in Romania in environmental auditing? This is the question we will seek to answer next, and for this we will rely on a study conducted by Ienciu on this subject in 2009.

We analyzed a series of significant aspects regarding the involvement of financial auditors in environmental auditing in Romania, such as (Ienciu, 2009):

- the experience of financial auditors;

- the affiliation of financial auditors to an entity that conducts environmental audits;

- the environmental responsibility of Romanian entities;

- the involvement of financial auditors in carrying out environmental audits.

Ienciu developed a questionnaire that was sent to 2234 auditors, receiving answers only from 276, representing 12\%. Regarding the experience of financial auditors in auditing, the analyzed parameters included seniority of auditors in conducting audits and the number of financial audits they conducted until now. The conclusion was that $72 \%$ of financial auditors have more than a year of experience in the field, while in terms of the number of conducted audits, $25 \%$ participated 
in over 20 audits and $9 \%$ in over 100 audits.

In terms of the affiliation of financial auditors to an entity that conducts environmental audits, most auditors are employed by different entities in Romania (43\%) and 53\% work as independent natural persons. The opinion of auditors regarding the responsibility of Romanian entities towards the environment was analyzed in terms of the importance given to environmental issues by entities in Romania. Most financial auditors think that Romanian entities give little importance to environmental aspects (53\%) or don't give any importance to them (38\%). Regarding the clarity and relevance of environmental information provided by Romanian entities about the environmental impact, the study showed that $98 \%$ of information is irrelevant and insufficient to reflect the environmental impact of the entities. The involvement of financial auditors in Romania in environmental auditing was analyzed with the help of the following variables:

- Professional experience in carrying out environmental audits. The study shows that only $8 \%$ of Romanian financial auditors have been involved in environmental auditing;

- The opinion of financial auditors regarding the involvement of the accounting profession and financial auditors in environmental auditing. $74 \%$ of the respondents consider that the accounting profession and the financial auditors should get involved in carrying out environmental audits;

- The future involvement of Romanian financial auditors in environmental auditing. The data of the study show that $41 \%$ of financial auditors are considering getting involved in future environmental audits.

- The factors that hinder the involvement of a financial auditor in environmental audits. $61 \%$ of financial auditors believe the main factor that hinders them to get involved in environmental auditing is the lack of a guide or standard regarding this field, the lack of technical knowledge in this area $(58 \%)$, the lack of professional qualifications needed to carry our environmental audits $(28 \%)$ and other factors $(23 \%)$.

Continuing the research conducted by Ienciu (2009) regarding the implication of Romanian financial auditors in environmental auditing, we prepared a questionnaire that, in addition to aspects regarding environmental audit, includes references about how entities manage the environmental problems they face. The questionnaire was sent to 210 entities in Alba County that operate in industry, services, commerce and agriculture, receiving responses only from 130 entities representing $62 \%$, a percentage that is statistically acceptable for our study. The question regarding the involvement of financial and accounting specialists in conducting an environmental audit or in preparing an environmental balance sheet, of the 130 entities that responded, 110 entities (84\%) said that they don't involve accounting professionals and 20 answered affirmatively (16\%). The second question referred to the option of whether the financial auditor during a statutory/financial audit assignment takes into account the environmental issues arising from the entity's activity. The answers received to this question follow the same direction, namely 90 entities $(70 \%)$ responded that the financial auditor had not taken into account environmental aspects and only 40 entities $(30 \%)$ responded that the financial auditor had considered these aspects and had made recommendations for the cases when the entities had been facing environmental problems that were not presented in financial statements.

We may note that the entities in Romania and Alba Iulia don't give significant importance to environmental aspects; the provided information is insufficient and irrelevant to reflect the environmental impact of the entity's activities. In terms of the involvement of Romanian financial auditors in conducting an environmental audit, their involvement is still little due to the lack of a general framework that stipulates these aspects and the lack of technical knowledge. Engineers represent the profession that performs most of the environmental audit because of their technical knowledge in the field. The involvement of financial auditors next to engineers, biologists, ecologists and environmental experts in performing environmental audits represents an advantage for the auditing of environmental information with financial features, such as environmental costs, 
environmental debts and environmental provisions.

\section{Conclusions}

Environmental audit is designed to help organizations fulfill their managerial commitment and control of environmental practices, complying with environmental regulations and company policies. As we have seen, environmental aspects have various impacts over the activity of the entity. Environmental issues may still be considered a relatively recent challenge for auditors, regardless of the fact that environmental responsibilities are undertaken voluntarily or by law.

There have been a series of reasons regarding the relevance of the audit profession in carrying an efficient role within environmental audit. Certain arguments claim that auditors may participate in environmental audits with other experts, such as: environmental specialists, engineers and lawyers. Nevertheless, the participation of auditors in environmental auditing is still quite limited.

There are a number of obstacles that impact this contribution. The aspects that limit auditors' participation in environmental audit are (Dixon et al, 2004) presented in figure no.

Obstacles, which limit auditors' participation in environmental auditing

\begin{tabular}{|c|c|}
\hline $\begin{array}{l}\text { Factors related to auditors and } \\
\text { the auditing profession }\end{array}$ & $\begin{array}{l}\text { Factors related to the companies' } \\
\text { lack of demand for environmental } \\
\text { Reporting }\end{array}$ \\
\hline$\downarrow$ & $\downarrow$ \\
\hline Accounting education & Environmental data information \\
\hline Ethical and social aspects in & Environmental indicators \\
\hline \multirow{2}{*}{$\begin{array}{l}\text { Research in accounting and } \\
\text { auditing profession }\end{array}$} & Environmental reporting \\
\hline & \multirow{2}{*}{$\begin{array}{l}\text { The need for independent } \\
\text { verification }\end{array}$} \\
\hline \multirow{2}{*}{$\begin{array}{l}\text { The experience, skills and training } \\
\text { of the financial auditor }\end{array}$} & \\
\hline & \multirow{2}{*}{$\begin{array}{l}\text { Professional standards and } \\
\text { princibles of }\end{array}$} \\
\hline \multirow{2}{*}{$\begin{array}{l}\text { Professional guidance on } \\
\text { environmental matters }\end{array}$} & \\
\hline & \multirow{2}{*}{$\begin{array}{l}\text { Limited public demand for } \\
\text { environmental reports }\end{array}$} \\
\hline \multirow{2}{*}{$\begin{array}{l}\text { Auditors' view towards involving } \\
\text { in environmental auditing }\end{array}$} & \\
\hline & $\begin{array}{l}\text { Nature of the demand for } \\
\text { environmental reporting. }\end{array}$ \\
\hline
\end{tabular}

Figure no. 1. The aspects that limit auditors' participation in environmental audit

Sursă: Robert Dixon, Gehan A. Mousa, Anne D. Woodhead, The necessary characteristics of environmental auditors: a review of the contribution of the financial auditing profession, Accounting Forum, 2004, vol. 28, p.134.

We reached the conclusion that the accounting profession, both internationally and nationally, is involved to a small extend in environmental auditing, which is due to the lack of 
regulations and general reporting frameworks. As evident from the research conducted among the entities in Alba County, financial auditors are only slightly involved the environmental auditing, but they can use the findings of environmental audit as audit evidences when conducting a financial/statutory audit assignment and when issuing the audit opinion within the audit report. As future research directions, we are considering disseminating the questionnaire for entities in other counties of Romania and writing other papers that will approach aspects related to environmental audit and the involvement of the accounting profession in conducting it.

The conclusions presented previously provide opportunities for new approaches regarding environmental audit and the involvement of financial auditors in performing environmental audits.

\section{Acknowledgements}

Financial support for this article has been provided through the project Bursele doctorale, premiza pentru cresterea competitivitatii si competentelor in cercetarea stiintifica, ID POSDRU/6/1.5/S/23 and ID POSDRU63269 implemented under the Sectoral Operational Program for Human Resources Development and financed by the European Social Fund and Government of Romania.

\section{References}

1. Bețianu L., Georgescu I., 2008. Approaches of environmental information audit in annual reports, Annales Universitatis Apulensis Series Oeconomica, vol.1.

2. Chiang C., Lightbody M., 2004. Financial auditors and environmental auditing in New Zealand, Managerial Auditing Journal, vol. 19, no. 2

3. De Moor P., De Beelde I., 2005. Environmental Auditing and the Role of the Accountancy Profession: A Literature Review, Environmental Management Journal, vol.36, no. 2

4. Darnall N., Seol I., Sarkis J., 2009. Perceived stakeholder influences and organizations' use of environmental audits, Accounting, Organizations and Society Journal, vol.34

5. Dixon R., Mousa G., Woodhead A., 2004. The necessary characteristics of environmental auditors: a review of the contribution of the financial auditing profession, Accounting Forum, vol. 28

6. Ienciu I. A., 2009. Implicațiile problemelor de mediu în contabilitatea şi auditul situațiilor financiare, Risoprint Publishing House, Cluj Napoca

7. International Chamber of Commerce, 1991. An ICC Guide to Effective Environmental Auditing, ICC Publishing, Paris

8. Hong Kong Government, 2004. Environmental audit: A simple guide, available online at http://www.epd.gov.hk/epd/textonly/, accesed in 20 January 2011;

9. Lungu C. I., Chirața C., Dăscălu C., Sahlian D., 2010. Concepts and policies of social and environmental standards and corporate reporting practice, Annals Economics Science Series, Timişoara, vol. XVI

10. Maltby J., 1995. Environmental audit: theory and practices, Managerial Auditing Journal, vol.10, no. 8

11. Parker L., 2005. Social and environmental accountability research: A view from the commentary box, Accounting, Auditing and Accountability Journal, vol.18

12. Peglau R, 2005. ISO 14001 certification of the world, Berlin: Federal Environmental Agency

13. Power M., 1997. Expertise and the construction of relevance accountants and environmental audit, Accounting, Organizations and Society, vol.22, no.2

14. Solomon A., 2000. Could corporate environmental reporting shadow financial reporting?, Accounting Forum, vol. 24. 